\title{
Social Resilience in Aegean Slow Cities: Slow City Seferihisar
}

\author{
Can Gunduz ${ }^{1}$, Asli Ceylan Oner ${ }^{2, *}$, Paul L. Knox ${ }^{3}$ \\ ${ }^{1}$ Department of Architecture, Izmir Institute of Technology, Izmir, Turkey \\ ${ }^{2}$ Department of Architecture, Izmir University of Economics, Izmir, Turkey \\ ${ }^{3}$ Virginia Tech, College of Architecture and Urban Studies, Blacksburg, VA, USA
}

Copyright $\mathrm{C} 2016$ by authors, all rights reserved. Authors agree that this article remains permanently open access under the terms of the Creative Commons Attribution License 4.0 International License

\begin{abstract}
Being open to global processes brings up the question of social resilience in Slow Cities, which is about the ability of the system to absorb shocks without experiencing changes [1]. Since these cities are inevitably affected by global flows and ideas, how will they be able to protect their identity? In this regard, Scott (2013) [1] defines two types of resilience: equilibrium and evolutionary resilience. Equilibrium resilience is about going back to normal, whereas evolutionary resilience is about adaptability and creating long term innovative planning and policy responses to change; embracing change and utilizing it as a path forward that needs to be embedded in social networks [1]. This paper proposes that evolutionary resilience is the key for sustainable growth of Slow Cities within a progressive framework and explores possible barriers and solutions to achieve evolutionary resilience for slow cities. The paper examines Aegean Slow Cities with a specific emphasis on Seferihisar, the first Cittaslow of Turkey as a case study.
\end{abstract}

Keywords Social Resilience, Global, Local, Slow City, Seferihisar, Aegean Slow Cities

\section{Introduction}

Slow Cities (Cittaslow) is a movement founded in 1999 in Italy that has spread to 191 towns in 29 countries. The Slow City movement is a response to the fast world under the influence of globalization and it advocates local distinctiveness and desire to protect the uniqueness of localities [2,3]. Cittaslow has a charter with 59 different aspects grouped into six different topic areas including environmental consciousness, support for local products, urban design and infrastructure, technologies and facilities for urban quality, hospitality, and embracing the Cittaslow philosophy $[3,4]$. Although the Cittaslow movement aims to provide an escape from the homogenized processes of globalization, it has become evident that the movement has been susceptible to global branding, attracting heritage tourism and marketing approaches, which affect the economies and growth policies of these cities [5]. Slow Cities are not isolationist destinations; like every other city, their governance system and social dynamics are affected by a global set of principles. Thus, as Pink and Lewis (2014) [2] suggest Slow Cities are very much located in the global-local nexus and in this regard the social resilience of slow cities becomes an important research topic. With their strong claim on authenticity of culture and built environment, slow cities have become magnets for affluent groups including global elite, which may provide a clash with the local community dynamics. This is the main reason that social resiliency is a major topic of research in the context of Slow Cities.

The paper is focused around the question of "since Slow Cities are highly affected by global flows and ideas, what are possible barriers and their implied solutions for Slow Cities to protect their identity?" To answer this question, we employ social resilience as a framework. The paper focuses on Slow Cities in the Aegean region of Turkey as a case study with a specific emphasis on Seferihisar. Turkish Slow Cities are among the least studied geographic context since the first slow city designation came in 2009. The existing literature tends to focus on tourism development rather than resilience and planning concepts (e.g. Ekinci (2014) [4]).

The paper has a descriptive case study method. Seferihisar, coastal city, was the first Slow City to be designated in Turkey. With 30,000 people, it has a local farmers' organic bazaar and there is an idea for a Cittaslow University, focused around art, architecture, agriculture. Seferihisar is already known as a major tourist destination. Focusing on Seferihisar will provide insight to the social resilience of Turkish Slow Cities from the planning and policy perspective.

The first part of the paper is a literature review that examines the concept of resilience and explores its applicability as a framework to study the Cittaslow idea. With the help of the literature review, the second part of the 
paper provides a discussion of the case study context of Aegean Slow Cities with a specific emphasis on Seferihisar area. The final section offers concluding remarks.

\section{Literature Review}

Resilience is a concept that has been widely explored in urban and rural studies especially after the global economic crisis of 2008. One thing that was unique about this crisis is that economic crisis was taking place at the same time with environmental crisis and climate change issues [1]. Thus, we are in crucial times to discuss the resilience of cities and communities [2]. The severe economic and environmental crisis in the beginning of the 21 st century may have been the reason for the resilience concept to supersede the discussions on sustainability of cities and communities. On the other hand, resilience discussions should not only be attributed to crisis. It is a term coined in systems ecology, which is described by Scott $(2013,598)[1]$ as 'the ability of a system to absorb or accommodate disturbances without experiencing changes to the system'. Thus, any outside impact on a system would create a reaction in terms of the resiliency of a system. In this respect, social resilience can be defined as how communities adapt to the political, social, cultural, economic, and environmental impacts imposed by market conditions [6], which in the contemporary period highly connected with the pressures of globalization.

When a system encounters a disturbance or outside impact, there are two possible outcomes: go back to normal or transform. Going back to normal is described as equilibrium resilience, which is the ability of a system to absorb shocks without experiencing changes, in other words bounce back of the system to the original state. There is no transformation as a response to crisis $[1,7]$. On the other hand, the system might be transformed when it encounters a disturbance. Non-resilient systems might fall apart (environmental disasters in cities are examples) or they might 'bounce forward' by encountering a transformation through integration of values that enable for better adaptability to shocks and disturbances [8]. This bounce forward approach is associated with 'evolutionary resilience' and it is more applicable in the planning and economic development literature for long-term solutions to problems and issues facing the communities [1]. Davoudi (2012) [8] argues that evolutionary resilience is more than seeing the space as a spatial container, but as interconnected socio-spatial systems with feedback processes at the multi-scalar level.

Pink and Lewis (2014) [2] discuss the concept of resilience in the form of evolutionary resilience in the context of Australian Slow Cities. They argue that Cittaslow provides a suitable context to discuss resilience due to the fact that this movement is seen as a resistance towards globalization and flows associated with that (outside disturbance). Slow cities are not isolated from external changes, the governments of these cities embrace change, but they do it in a way to preserve their uniqueness by following guidelines and policies. Following Massey (2005) [9] Pink and Servon (2013) [10] contribute to this discussion with the suggestion that then the word resistance might not reflect the reality since local space and urbanization trends cannot be defined in isolation from the global. Rather, they are relational concepts. Thus in the case of Slow Cities we need to look at how the global interacts with the local to shape identity and authenticity. Such interaction is inevitable, so the issue is how slow city governments, activists and residents can advance the wellbeing and quality of life in their communities within the framework of Cittaslow $[2,11]$, in other words how Slow Cities can achieve social resilience in the evolutionary format.

At this point, it will be useful to describe the Slow Cities (Cittaslow) movement. It was formed in 1999 by the mayor of Greve-in-Chinati in Italy and quickly embraced by the mayors of Bra, Positano and Orvieto. Cittaslow is closely linked with the Slow Food movement and as it is described in their website, cittaslow.org, the movement is defined as providing an environment which demonstrates the characteristics of 'the slow and healthy succession of seasons, respectful of citizens' health, the authenticity of products and good food, rich of fascinating craft traditions of valuable works of art, squares, theaters, shops, cafés, restaurants, places of the spirit and unspoiled landscapes, characterized by spontaneity of religious rites, respect of traditions through the joy of a slow and quiet living'. By early 2016, Cittaslow had 191 member cities from 29 countries.

Cittaslow has a charter with 59 different aspects grouped into six different topics including environmental consciousness, support for local products, urban design and infrastructure, technologies and facilities for urban quality, hospitality, and embracing the Cittaslow philosophy [3,4]. To become a member, towns must have a population of less than 50,000 and satisfy at least 50 percent of the 59 points set out in the charter. In addition, they need to make a pledge to advance their Cittaslow related characteristics. Certification is given for four years [10]. Member and candidate cities have to have strong commitment to sense of place and authentic identity achieved through careful considerations of urban design and planning. Conservation of the built environment, supporting local industries and introducing modern ones, creating more green space and pedestrian and bike circulation, reducing visual and noise pollution, and growing local produce are the most important issues [5]. The role of the mayor is critical in the designation of Slow City character since it represents a new political dynamic [5].

Contemporary globalization, which involves the attenuation of the nation state concept coupled with transnational flows and market liberalization, more and more small towns have to rely on their assets to shape their future in order to avoid being victimized by external neoliberal political and economic forces associated with globalization [5]. In this regard, Cittaslow has the potential to offer an innovative framework and an alternative urban development model [3]. Although the Cittaslow movement aims to provide an escape from the homogenized processes of 
globalization, the movement has been susceptible to global branding, attracting heritage tourism, amenity migration from affluent groups, and place marketing approaches [5]. Thus, Slow Cities are in fact located in the center of the global-local nexus [2]. In this global-local nexus, it is important to understand how Slow Cities can be resilient and progressive together with the possible barriers to achieve evolutionary resilience resulting from, globalization related trends.

Some grassroots movements, including Cittaslow, have started to emerge in small towns, creating an openness to alternative urban development models [5]. As Massey (2007) [12] points out, the global is locally produced as much as local is impacted by the global. The Cittaslow framework allows towns to draw on their own distinctive attributes and comparative advantages, which in turn makes for an important precondition for resiliency [10].

On the other hand, a study of English Slow Cities suggests that the Cittaslow philosophy has been a concept embraced mostly by committees and leaders rather than their communities [11]. Residents are not always fully aware of the benefits and the gaps, which has also been the case in Turkish Slow Cities as will be explained. However, Pink and Lewis $(2014,3)$ [2] argue that 'The adoption of Cittaslow principles and framework is always embedded in and interwoven with the ways in which towns' people experience being, knowing, and doing everydayness in their homes, streets and public spaces...' If residents are more involved in the making and living with the Cittaslow framework through their experiences of place, they will embrace the idea more and the movement will become more bottom-up, which means that the community will be more resilient to changes introduced from outside. Adoption of innovative strategies to assert the uniqueness and authenticity of these places evidently needs to be formulated with the communities rather than with designated committees or only by leaders. Also, changes took place in these communities after becoming a Slow City needs close observation due to the threats of gentrification and falling into the gap of brand recognition for only marketing purposes. Local and global also needs to be embraced as relational and resiliency should be perceived as a multi-scalar phenomena. The important point is that Cittaslow is a global movement to escape from the fast world of globalization. The movement defines an alternative system of urban and economic development, which has the potential to make cities more resilient to market forces especially in terms of global system shocks. However, the concept of resiliency in the Cittaslow context should not be about staying unchanged or unaffected, it should be more about furthering the community dynamics in a better way by utilizing the embedded social networks and authentic physical, cultural and social character.

To that end, Cittaslow brings the 'urban middle-classes' as stakeholders back into the arena of urban politics as important actors in urban governance networks capable of achieving social resiliency. In the context of the Slow movement, Carp (2011, 119) [13] proposes the term "adaptive co-management" in order to refer to the "place-based process of incremental intervention", which is ideally performed, according to Schultz (2009; in Carp (2011)) [13], "by a diverse network of actors to enable a balance between the coordination capacity of centralized structures, and the learning capacity of decentralized structures [where the] core features are learning, collaboration, and multi-level governance". In this renewed framework of the spatial turn in governance studies, the notion of "emergence" is given a privileged theoretical role with regards to the constitution of new sites of 'struggle' in the form of new research agendas to be 'reflexively' coordinated by a network of engaged scholars, intellectuals, activists, and most importantly, local administrators. For instance, the Regions and Cities Book Series, published by Routledge in 2012, has devoted a whole volume to the topic of Cultural Political Economy of Small Cities, presenting a body of academic work that contributes "to an emerging small cities research agenda and to the development of policy-relevant expertise that is sensitive to place-specific cultural dynamics" (Lorentzen \& van Heur, 2012) [14]. In this volume, Cittaslow is discussed as an international network of small towns in the European context with reference to the notion of "reflexive polycentricity" by Knox and Mayer (2012) [15], in order to emphasize the novelty in Cittaslow's 'governmentality' with respect to the "institutional polycentricity" of the EU's new regional policy substratum, from which Cittaslow emerges. Knox and Mayer $(2012,149)$ [15] reserve the notion of "reflexive polycentricity" to those "ad hoc networks of small towns":

"As (some) small towns have become increasingly collaborative, extending their focus from a national to an international frame of reference, and becoming involved in cross-border collaborative networks, they have begun to exhibit a bottom-up reflexive polycentricity, complementing the up-down formation of structures and mechanism of institutional polycentricity."

The examples, in this respect, are the Swedish network of eco-municipalities, the so-called eco kommun network and the Cittaslow movement, the latter being "the example that best represents the notion of reflexive polycentricity" as stated by Knox and Mayer $(2012,149)$ [15]. In this respect, the two examples are presented in a rather evolutionary manner; while eco-municipalities seem to operate within the singular framework of a "small is beautiful" imperative that prioritizes fossil-fuel independency as a central issue (i.e., the development of 'appropriate technologies' such as biomass heating systems, bio fuels), Cittaslow towns are favored for their 'openness' to (self-) reflexively develop tailor-made imperatives as fit to the 'assets' of the 'places' of concern. Slow Cities, in this sense, subordinate the concerns about sustainability to a pragmatics of place-based quality-of-life that proactively supports programs and projects in areas such as environmental protection, urban 
design and historic preservation, local food systems, hospitability and tourism, as well as building awareness among residents and guests about the slow philosophy.

Slow Cities are increasing in number and the size of their population. The average growth rate of the number of residents over the past ten years has been 12 percent [10]. This shows that the movement has attracted certain level of recognition. Thus, as discussed, recognition also brings branding and marketing issues that might pose a challenge to social resilience. The important issues are how the slow city framework is internalized in the community and what type of policies are established in the context of Cittaslow idea to create social resilience. The next section discusses the resilience concept in the context of Aegean Slow Cities in Turkey, specifically focused around the first Cittaslow: Seferihisar.

\section{The Case Study Context}

Among the 192 Slow Cities in 29 countries, Turkey is in the fifth place with in terms of number of Slow Cities with nine designated as Cittaslow. Italy has 74, Poland has 18,
Germany has 12 , and South Korea has 11 . This suggests that local governments in Turkey are aware of the Cittaslow movement and they are looking into this as an alternative urban development agenda. There are three cities listed from the Aegean Region including Seferihisar, Yenipazar, and Akyaka. Three cities from the Marmara Region including Gokceada, Taraklı and Vize; Yalvac from the Mediterranean Region, Halfeti from Southeastern Anatolia and Persembe from the Black Sea Region are listed as Slow Cities in Turkey.

The very first Slow City designation in Turkey came in 2009 with Seferihisar in Aegean Region. Home to Antiquity, the Aegian Region of Turkey is known as a politically and culturally progressive area (Figure 1). Especially the coastline area has historically been connected with many cultures. The region is also rich in terms of agriculture and local produce. In our study, the initial idea was to have a case study of three cities: Seferihisar, Yenipazar and Akyaka (Figure 2). This initial study would be to understand and compare the three Aegean Slow Cities in terms of social resiliency. The events that took place during 2014 have added interesting layers to our study.

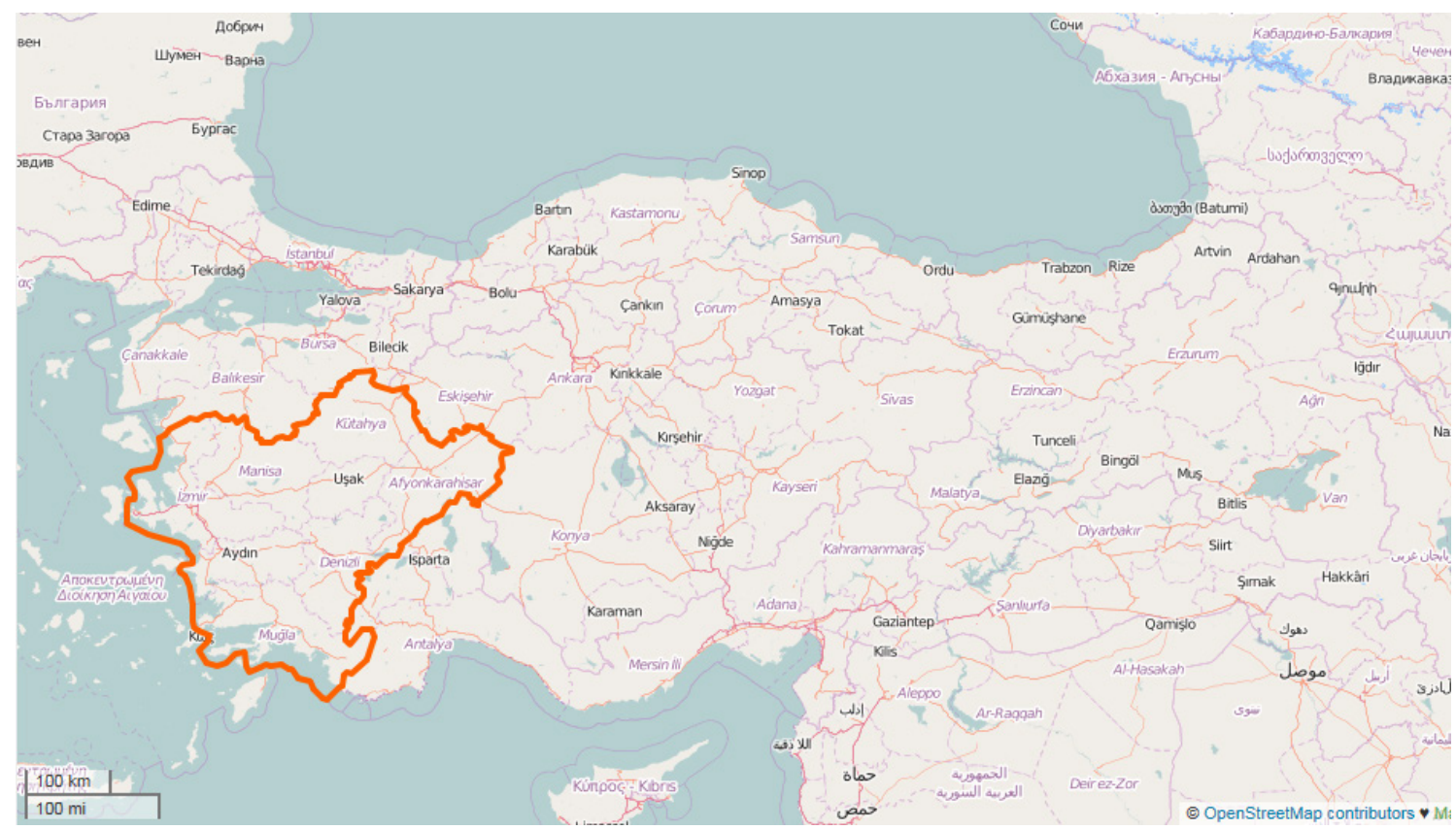

Figure 1. Aegean Region of Turkey (Source: Open Street Map) 


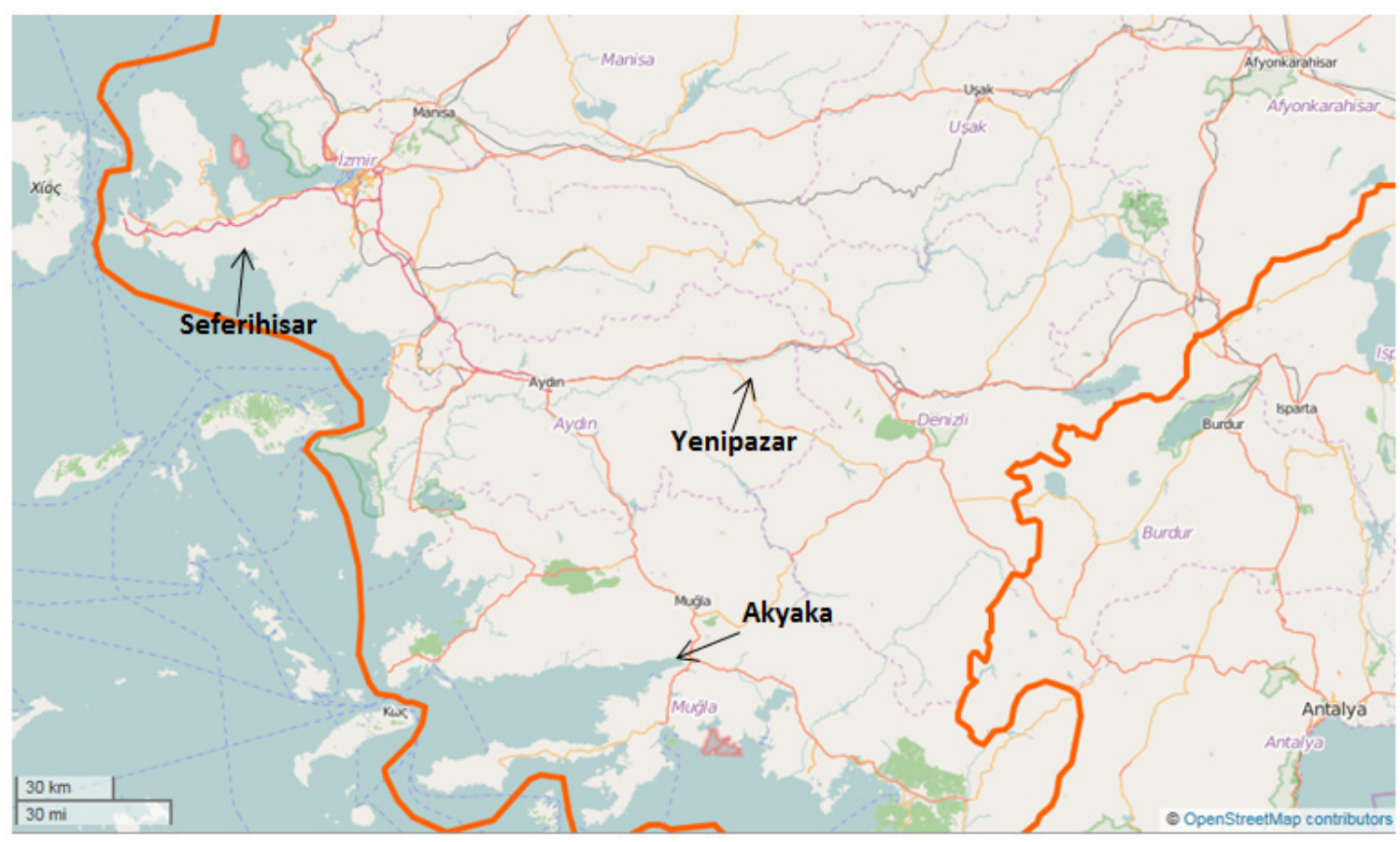

Figure 2. Aegean Slow Cities (Source: Open Steet Map, illustration by the authors)

The story about Yenipazar is worth mentioning as an example of how evolutionary resilience was not achieved. Yenipazar is an inland city in the Aydin province. The population is around 6,000. Yenipazar is known as the location of the nomads and EFEs (unofficial, but organized groups that fought during the Turkish War of Independence). These groups have a distinctive culture with special songs and dances. Yenipazar places a lot of importance on bicycle transportation. They also have their local cuisine and specific dishes which are well-known in the region. As part of the vision of the mayor elected from the left wing political party in 2011, Yenipazar was chartered as Cittaslow. However, this designation was not communicated properly to the community. Slow City became associated with being slow... On April 2014, there were local elections in Turkey. In this election, the mayor lost the election to the right wing candidate, who said that 'Yenipazar will not be a slow city, it will be a productive city, nothing has changed since the Slow City designation'. This was the first promise of the new mayor. The previous mayor from the left wing party also said what they tried to do did not match with the public interest and played a big role in his defeat in the elections [16].

The Yenipazar example is actually a very powerful example in terms of how social resiliency was not achieved due to lack of interaction among community and leaders. Since the process and the concept were not communicated efficiently to the public and the community was not given an active role, they could not grasp the concept and did not use the Cittaslow framework as a bounce-forward approach. Yenipazar is still in the list of Slow Cities, but after these events the future is unknown. Similar issues took place in other Turkish Slow Cities. In 2014 elections, the mayors of Persembe and Vize also lost the elections for similar reasons.
The Slow City is perceived as a city that is quiet, which is actually a literal translation problem [17]. Akyaka, which was chartered in 2010, currently became part of the Ula Administrative Region and according to the new subnational regional scale designation (Scale Reform Law) it lost its city status. The future of the Slow City designation of Akyaka is yet to be determined. This new designation in the Scale Reform can cause changes in the jurisdiction of decision making bodies in other slow cities as well and demands further focus.

In Turkey, the introduction of the 'subnational regional scale' within Turkish state space is a very recent issue accompanying Turkey's stuttering EU accession process. In 2002, following the landslide victory of the Justice and Development Party (AKP) in the general elections, the government committed itself to meet all the EU criteria on regional policy via Public Sector Reforms. ${ }^{1}$ Following the formation of new statistical units at the regional level (NUTS-2), 81 provinces have been gathered in 26 new regions according to their similar geographic and economic characteristics. The setting up of the Regional Development Agencies (RDAs) was another significant step toward the implementation of subnational regional development policies as well as EU's structural funds at the level of the

\footnotetext{
${ }^{1}$ Beriş and Dicle (2004) discuss how “Turkey's public administrative system remained ineffective and failed to match extensive economic liberalization that took place in the 1980s. Recognizing this gap and Turkey's low performance compared to many other countries around the world, the AKP included Public Sector Reform into its Urgent Action Plan in 2002, in addition to its government program." Beris, Yakup; Dicle, Ebru (March, 2004)"Reforming Public Management and Managing Reform in Turkey" in TURKEY in FOCUS, Issue: 4.
} 
NUTS-2 regions in accordance with the EU accession process. The following step has been to reach out to the municipal scale in order to encourage the relations between municipalities and other bodies as well as the formation of unions among local administrations, strengthening the legal framework for NGOs [18].

Currently, the Local Administration Reform is in its second phase and as a report prepared within the scope of the "Support to Further Implementation of Local Administration Reform in Turkey Project (LAR Phase II)" reveals, several European models of municipal cooperation are being reviewed by the Ministry of Interior to be advised as networks "that can support the deeper integration of Turkey within the international community". It is interesting to note that, in this report Cittaslow is suggested as a suitable cooperation network for smaller municipalities. ${ }^{2}$ Thus, although Cittaslow's entry ${ }^{3}$ into the Turkish municipal scene was enabled by the individual entrepreneurial efforts of the mayors, it is important to note that Cittaslow became a government-approved organization [18] besides its academic status as a "legalized approach to claiming the urban" [11].

\subsection{Social Resilency and Seferihisar as the First Slow City of Turkey}

The concept of social resiliency refers to a renewed dialectic between governmental 'structure' and 'strategy'. On the side of the structure, aside from the nation-state level of governance, we have the use of multi-scalar meta-governance and the multiplication of institutional forms and regulatory mechanisms; and on the side of strategy, aside from class struggles, we have the new social movements and many other reflexive forms of social action. Given the multifaceted problems of reconciliation of a 'policy-laden' institutional turn with a 'value-laden' politics of collective action, a 'city-based' governmental 'movement' such as Cittaslow is mostly relying on the intellectual, as well as the mobilization capacities of its notable members.

In that respect, the mayor's role is key in the designation of Slow City character as a new political dynamic in town. Tunc Soyer, mayor of Seferihisar, is a notable urban-elite

\footnotetext{
${ }^{2}$ Jackson, John \& Üskent, Sezin (September, 2010) Municipal Partnerships Support Network, report prepared within the scope of the "Support to Further Implementation of Local Administration Reform in Turkey Project (LAR Phase II)" which is financed by the EU and executed by UNDP for the Republic of Turkey Ministry of Interior Affairs. LAR website: http://www.lar.org.tr/uploaded/dosyalar/b27982bb5c46f1 c06b5a485aafa7b c45.pdf (Accessed: 02.05.2012).

${ }^{3}$ In fact, in Turkey, municipalities actually require prior authorization of the Ministry of Interior in order to join an international organization. An amendment regarding this Law is brought up in the latest monitoring report of the European Council's Congress of Local and Regional Authorities, $20^{\text {th }}$ session (1 March 2011): "The Government should seek to amend the Law on Unions to remove the need for Ministry approval of overseas links for municipalities" (CG(20)6, 2011:III.10 and V.52.g).
}

figure within Izmir's aspirational world city pursuits. He served as the Secretary General of the Izmir EXPO 2015 Executive Committee during the three-year-long candidacy process, which entrusted him with extensive authority. A year after BIE announced that Milan would host the EXPO over rival Izmir, Soyer ran on the Republican People's Party ticket in the 2009 local elections and took office in the 31st of March 2009. Six months after his election, Seferihisar was chartered as the first slow city of Turkey, which also gave the city the status of the Cittaslow Capital and coordinator (Figure 3). Seferihisar's Cittaslow membership was deemed important for becoming a global tourist destination with resources of natural and cultural conservation [19].

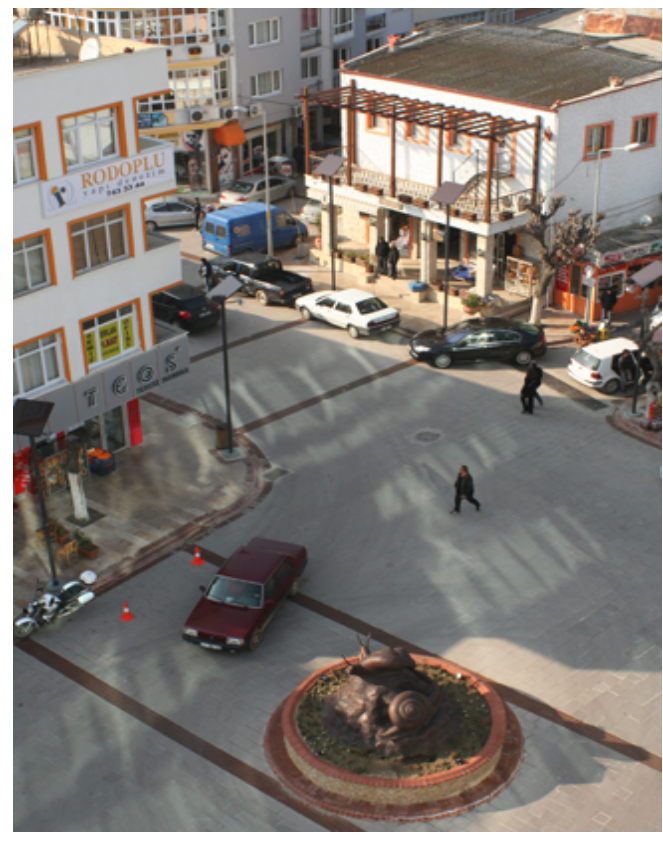

Photo credit: Can Gunduz

Figure 3. Seferihisar Town Center and the Cittaslow Sculpture

In the following couple of months in 2010, the Cittaslow criteria were quickly adopted and adapted by the municipality not only as a guide for action but also in compensating for the general 'lack of identity' in the town, which had been growingly experienced as a 'governance failure' for the unsuccessful management of its distinguished natural and historical assets. Thus, Cittaslow was mobilized as the umbrella 'concept', through which the municipal team, with members from the mayor's previous İzmir-EXPO team, started to coordinate and introduce several other projects, events and organizations in order to transform the town into a 'slow' world city, where the local brings forth its culture as a constantly experienced 'tourist-attraction-event'. This vision culminated in mayor's merging the Cittaslow concept with that of the International EXPO, by which he introduced the idea to create a fair area where 25 countries can come together and display the most appropriate Cittaslow examples and introduce their countries in a couple of months long event.

After the designation, in 2010, a master plan was prepared for Seferihisar with a local university (Yalcin and Yalcin 
2013) [20]. In subsequent years, Seferihisar has implemented many innovative programs as a Slow City. Among these projects, the most important ones have focused on organic agriculture and empowering women. In terms of agriculture, Seferihisar has several organic bazaars, where the local farmers sell their produce. The bazaar in the city center is open six days a week. On Sundays, there is a bazaar in Siğacık area, in which not only farmers but also women sell different types of crafts and prepared food. Other projects include the Seed Trade Festival, a restaurant for local cuisine (Sefertasi), gathering places for women like coffee houses, cycling lanes, tree blue ribbon beaches (Akarca, S1 ğacık and Urkmez), support for sustainable fishing, use of solar and geothermal energy, promoting the hot water bath tourism, conservation of the historic Teos Antique City ${ }^{4}$, and restoration and landscaping of the Siğacık area.

Seferihisar has a planned program for "an author in residence", in which they would like to invite a well-known author to stay and work there and also interact with the residents for an extended time. Membership to the European Drama Encounters brought many students and drama artists in 2012 to the city. Seferihisar municipality also has a plan for a Cittaslow University, focused around art, architecture, agriculture. In addition, Seferihisar is the only Cittaslow in Turkey with a childrens's council, which granted it the status of being a child-friendly city per UNICEF's designation. In order to create a collective memory for the history of the area and the traditions, Seferihisar also has 75 plus parties to listen to elderly people and record the verbal history as told by them $[19,20]$.

All of these projects are innovative and define a leading role for Seferihisar among the other Slow Cities in Turkey. On the other hand, how much of social resilency does Seferihisar have? Is the planning process open to public at all levels? Has Cittaslow framework helped to form or reinforce a cohesive community character? Based on the interviews with local residents Ozgen (2012) [21] concludes that although there are attempts to involve public in the decision making process and Cittaslow has a positive impact on the quality of life in Seferihisar, the public still feels they are not fully part of the process. The public is concerned about the impacts of the population growth to the city's small town character.

The effects of the Scale Reform Law on Seferihisar also create a problematic case for Seferihisar's social resiliency. Following the enactment of the Scale Reform Law of 2004 $\left(\mathrm{n}^{\circ} 5216\right)$ on 'Establishing Districts in the Borders of Metropolitan Municipalities' and the Municipalities Law of $2005\left(n^{\circ} 5393\right)$, Seferihisar municipality has lost most of the decision-making authority over its territory to the disposal of the Metropolitan Municipality. This situation significantly ties the hands of the local administration in putting plans into operation for the use and the development of their natural assets such as rich geothermal energy resources [18]. With the same Law, the two formerly $2^{\text {nd }}$-tier municipalities have

\footnotetext{
${ }^{4}$ Ionic city, which had the first association of artists and is recognized as the initator of theamphi- theater concept.
}

been incorporated as districts to the central municipality of Seferihisar, critically jeopardizing the 'subsidiarity' principle in the provision of the public services to these peripheral settlements. The same goes for the large military zone area in the middle of the district disconnecting the center and the periphery as well as repelling touristic investments. The development areas of Seferihisar are provided in Figure 4. Large forest areas are under constant threat of sabotage fires as well as the vast natural and historical protection sites that cannot be integrated into the everyday life of the inhabitants; consequently, regarded as obstacles in front of the 'development' of the town [18].

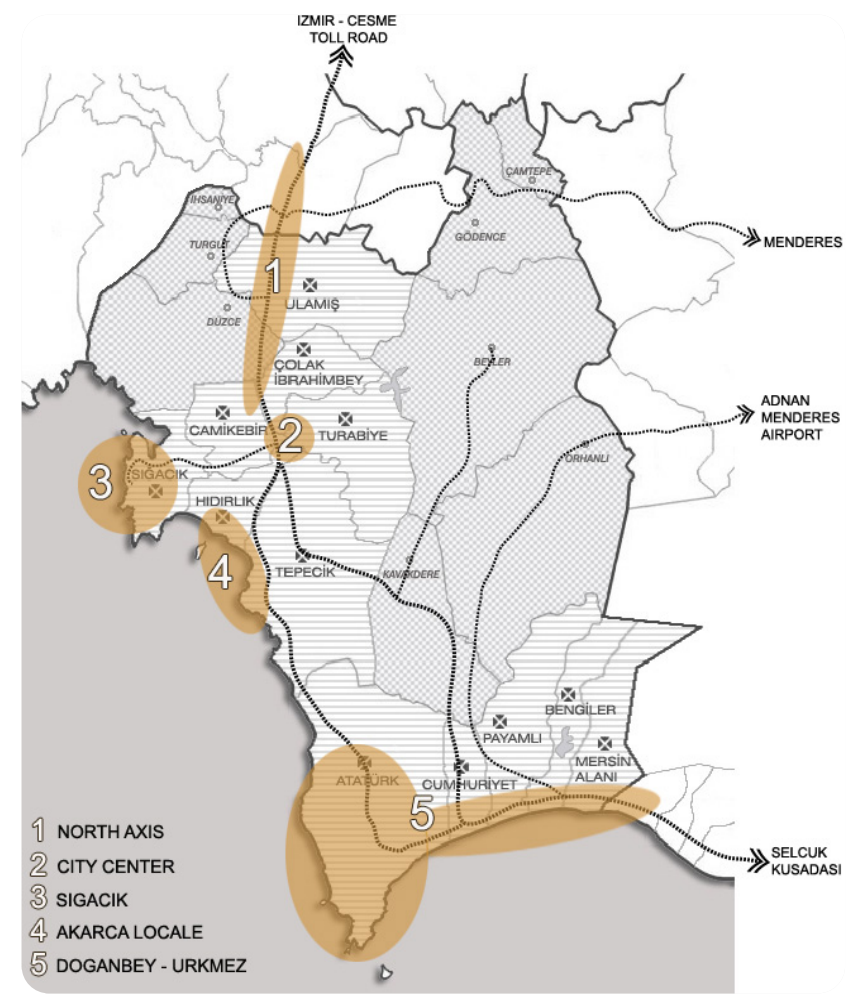

Illustration: Can Gunduz

Figure 4. Districts and Villages of Seferihisar with the Development Areas Marked

There are some other issues related to the social resiliency in Seferihisar. First of all, Seferihisar is on a major fault line, and there are over 200 unorganized summer house cooperatives in the district, which comprise disparate vulnerable settlements, some of them with serious infrastructural problems due to landslides on the shoreline. The seasonal in and out flux of the population in these secondary residence settlements also leads to social problems due to the weakened community connections as well as exclusion and segregation with the increase of gated communities [18]. On the other hand, the sudden rise of wealth in the local community during the 1960s with the transition to tangerine cultivation seems to have engendered an agricultural rentier class, the younger generations of which lack the adequate skills and the disposition to take part in the possible new 'political economic' futures of the town. Today, not only that there are already several incidences of 
volatile substance addiction among the youth, in the absence of policies specifically addressed to these social problems, it is very likely that these younger generations will end up finding themselves in the position of the 'undeserving poor' in the very close future [18].

In his $2^{\text {nd }}$ Year Speech, the mayor referred to the strategic role of Siğacık, the historic seaside citadel neighborhood of Seferihisar (Figure 5), as the "showcase" of the town, whose task was "to attract the customer inside the shop". Particularly, the organic produce market set up inside the citadel established Siğacık as an important weekend destination for people of the metropolitan area (Figures 6-8).

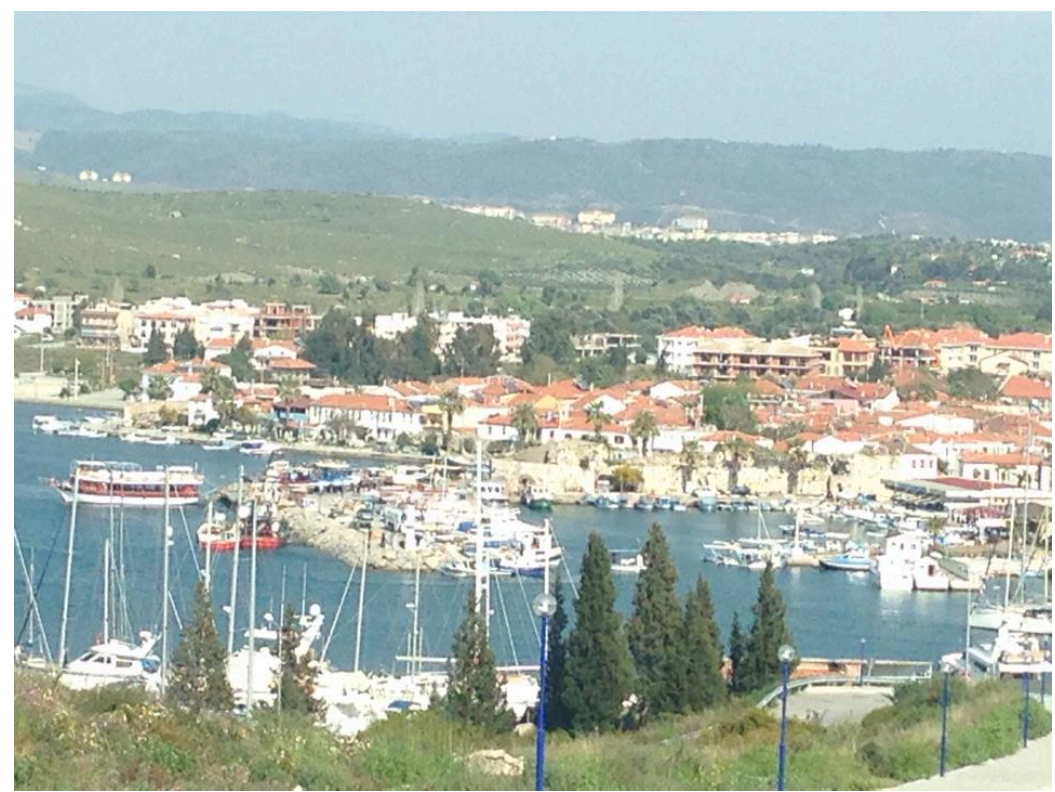

Photo credit: Asli Ceylan Oner

Figure 5. Sığacık Port Area

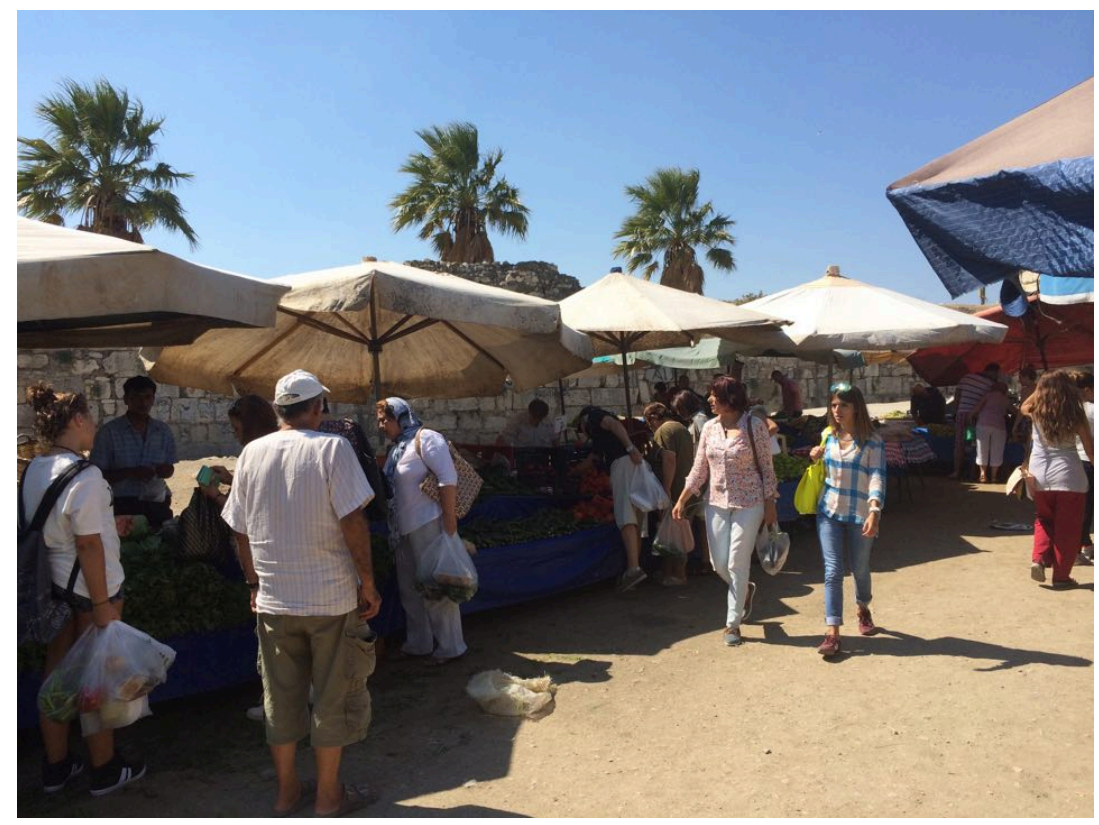

Photo credit: Asli Ceylan Oner

Figure 6. Organic food and produce market in Sığacık 


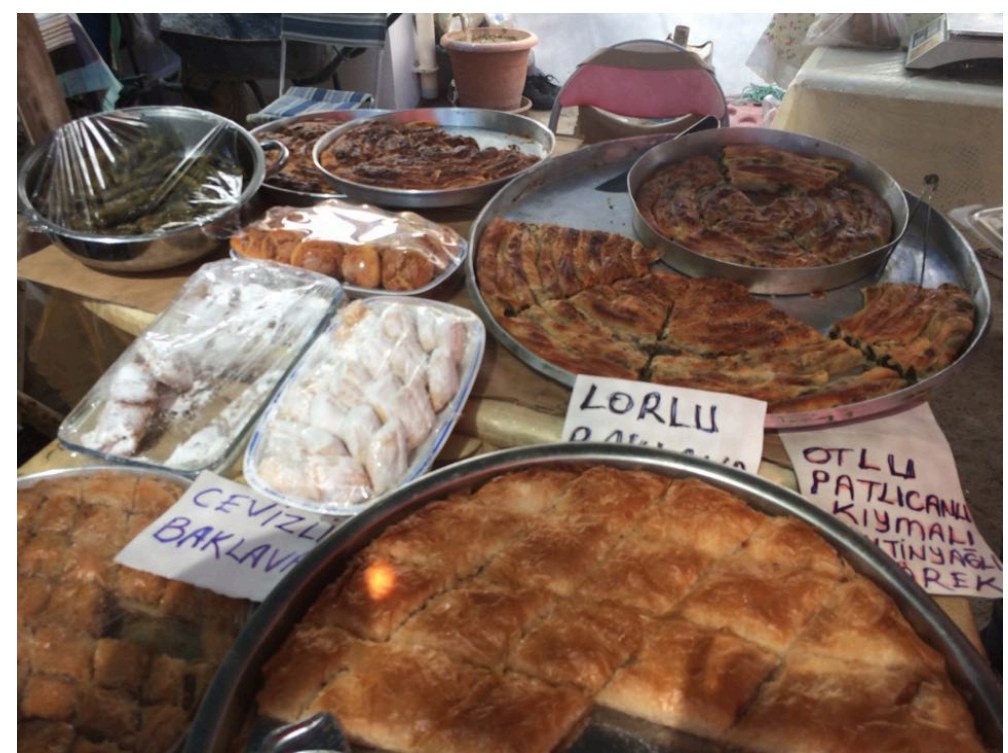

Photo credit: Asli Ceylan Oner

Figure 7. Food prepared by local women of Sığacık sold in the organic bazaar

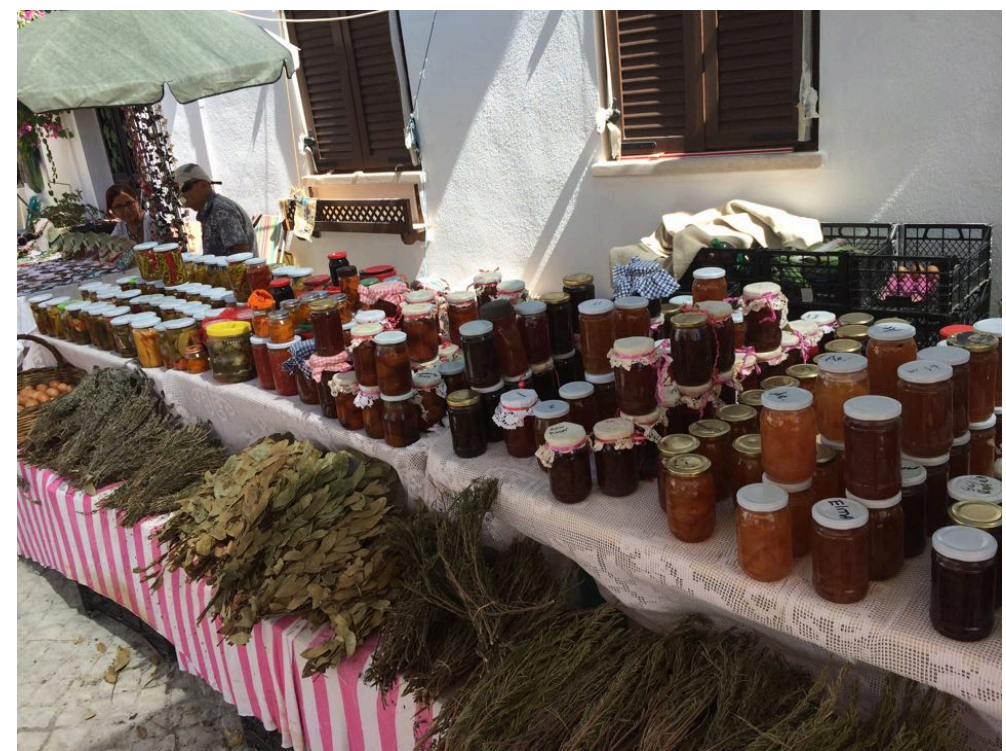

Photo credit: Asli Ceylan Oner

Figure 8. Organic food and produce market in Sığacık

In terms of building an overall city governance regime, however, this 'role' put Siğacık in a privileged status with respect to both the central town and the peripheral settlements, which openly expressed their discontent about the regarding of Cittaslow as the sole 'economic imaginary' of the whole district. Given the substantial role of the poor villagers at the Producers' Market in town's organic branding, the mechanisms for returning the overall real estate surplus back to all the segments of the society are not quite in place, nor in the scope of the mayor's future agenda.

Another ambiguous aspect of relying heavily on events and organizations in the governance of the town's issues is that it implies a transition to a new paradigm in town from a 'disciplinary' vision of organization of labour, to a 'communicational' and 'event-based' one... The producers' markets, seed swap festivals, fish farm protests, all successfully attract the target-classes to Seferihisar, whose intermittent corporeal co-presence has a sustainable economic influence on its own. Currently the Directorate of Culture and Social Works comprises of the most crowded office at the municipality to organize all kinds of events and organizations, as well as the routinely conducted educational activities for the residents of Seferihisar. Given the scale of the municipality and the strategic prominence to organizing events by Tunç Soyer, it would not be inappropriate to say that the whole municipality is run like a Directorate of Culture and Social Works, only shifting their duty priorities according to the agendas on the calendar. The municipality personnel admit that they experience this as an exhausting ongoing "total mobilization" mode, which inevitably 
distracts the everyday efforts to form a participation-based steering platform for Cittaslow.

The first Cittaslow Festival was organized as a two day activity that started with the Protest Meeting of the Bluefin Tuna Fish Farms. The 'protest' was observed as a strategic event in itself to consolidate Seferihisar's 'mode of governance' as much in the eye of the central authorities as in the general public. It was organized on the occasion of the controversial 'approval' decision of the Izmir General Provincial Council to set up a Bluefin Tuna Fish Farm at a few kilometers off the coast of Siğacık. Although the idea of setting up a rally belonged to the mayor, it was organized by the recently established Seferihisar city council. The head of the city council explained that buses were sent to every other district of Izmir to carry 1000 city council members to Seferihisar on the day of the protest; Greenpeace and several bicycle groups from Izmir were also invited to provide support to the protest. However, the local people were quite indifferent to the event; neither did they participate in the creation of a romanticized image of the 'residents battling growth machines'.

In this regard, the mayor seems to be rather muddling through the urgent economic demands from the general public by enticing earlier standstill touristic investments that will not hopefully conflict with Cittaslow's imperatives while somehow creating steady mass-employment opportunities. In that regard, Cittaslow seems to present rather long-term prospects for the creation of further employment in the town, which will be fully realized as the individuals and the currently developing associations grasp the entrepreneurial mechanisms of cultural and social economy. For the long-run, however, the municipality periodically conducts several educational activities, seminars and certificate programs in order to develop entrepreneurialism and to inform people about the funding opportunities for the opening of small-to-medium enterprises.

In the meantime, the increasing number of contractors in town, seem to regard "Cittaslow" simply as a branding mechanism that will make Seferihisar appealing for upper-middle class investments. The brochure in Figure 9 displays a famous national real estate company commissioned to market a 350 decares of state-owned property. The land has been quickly parceled with a local development plan in order to create a "Gardencity" theme. The marketing brochure uses the Cittaslow logo unabashedly next to luxurious suggestions for filling up the backyards of the villas.

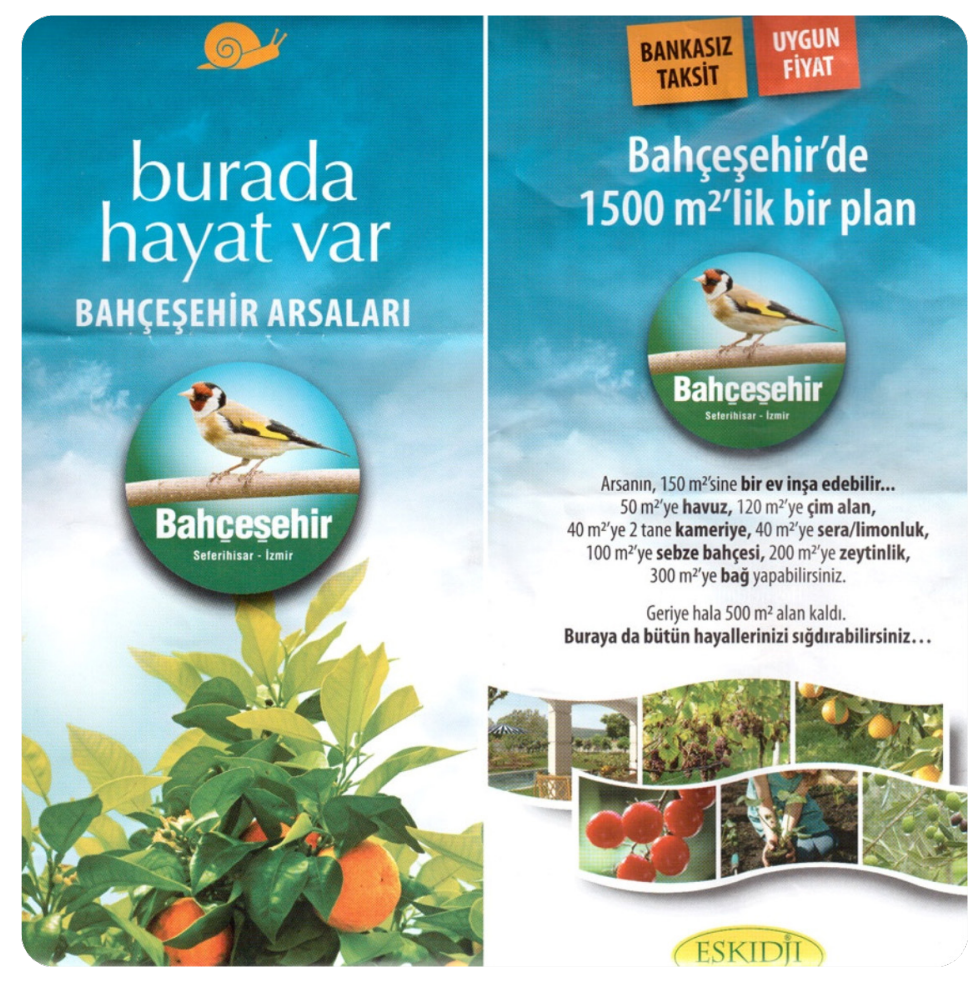

Figure 9. Gardencity theme development in Seferihisar 
A Cittaslow branded town derives its 'participatory' powers from the fact that it gives middle class individuals the chance to differentiate themselves simply by experiencing it. In that sense, Cittaslow enabled Seferihisar to put itself on the 'market' with an 'identity' distinct from all the nearby coastal towns. In other words, the effective 'differential' representation of the urban space "as lived", hopes to lure the 'responsible-action-seeking' individuals ('slow subjects') by promising them a 'reflexive' middle-class distinction (e.g., becoming slow), whose embedded protocols of experience are tentatively laid out in the Cittaslow Charter. In the single act of place branding, the town hopes to transfer its structural (political-economic) problems onto a separate (cultural) plane, as the 'matter of concern' of everyone interested in the opportunities linked to the experience of the brand; not 'collectively' as a 'community', perhaps, but rather as a new governmental whole.

\section{Conclusion}

In this paper, we have discussed social resilience and according to Scott's (2013) [1] definition; and we have argued that evolutionary resilience can be considered as an innovative framework to analyze the global-local nexus in Cittaslow movement. Global branding, attracting heritage tourism and marketing approaches, amenity migration, and gentrification resulting from globalization related pressures are presented as the main barriers to achieving social resiliency in Slow Cities. The literature review and the case study have indicated that the evolutionary resilience can be achieved through a bottom up process with the residents of Slow Cities taking a lead on the planning and governance issues and forming strong social networks that manifest and further the local identity. In addition, reflexive polycentricity concept also indicates that the exchanges of knowledge and information within the network of Slow Cities also contribute to social resilience in the evolutionary format. In this regard Aegean Slow Cities, including Seferihisar, do not show high levels of social resilience. The obstacles in Seferihisar's social resiliency are multifold. First of all, there is no coherent agreement in terms of how the Slow City concept is internalized among the Slow Cities of the Aegean Region, which leaves Seferihisar rather isolated. The National Scale Reform creates a level of uncertainty in terms of the jurisdiction of the local government and how the new development areas will be shaped in Slow Cities. In terms of social resiliency of Seferihisar, while Cittaslow is by no means the answer to the problems, it takes on the role of the 'cultural vanguard' in the "governmental" transition from the golden age of Fordism and its Keynesian Welfare National State with the dominance of the national scale in economic and social policy-making to post-Fordism and its associated "rediscovery of the heterogeneity of place, a relativisation of scale, and a multiplication of nodal scales for delivering economic and social policy" Jessop $(2009,85)$ [22].

Cittaslow in Seferihisar presents itself as an ongoing fuzzy project in terms of social resiliency, which derives its plausibility from the mayor's effectively positioning the town as an 'object of governance', a common 'matter of concern' for everyone, primarily for those 'old' and 'new' middle classes, who are located in the multi-scalar territorial space of Izmir, not only the local town dwellers, but also the day-based tourists from Izmir, activists and scholars from all over the place, constantly relaying the message that the 'success' of this project is as equally dependent on the proper conduct of governance as it is on everyone's attendance to its 'experience economic' agendas. The Cittaslow philosophy is not yet well embedded in the social networks within the city, but remains as a new innovative concept introduced by the mayor. There is no question that throughout the Cittaslow process Seferihisar has been an innovative leader city with the strong mayor determined to implement the Slow City principles. However, Seferihisar is also on the verge of falling into the gap of brand recognition and marketing issues by becoming a place destination as a "slow magnet". The local population is empowered to a degree with the bazaars and activities, but whether or not this will be enough to protect the local identity still remains ambiguous.

\section{REFERENCES}

[1] M. Scott. Resilience: A Conceptual Lens for Rural Studies?, Geography Compass, Vol. 7 No.9, pp.597-610, 2013.

[2] S. Pink, S., T. Lewis. Making resilience: everyday affect and global affiliation in Australian Slow Cities, Cultural Geographies, February 2014, pp. 1-16, 2014.

[3] H. Mayer, P.L. Knox. Slow Cities: Sustainable Places in a Fast World, Journal of Urban Affairs, Vol. 28 No. 4, pp.321-334, 2006.

[4] M.B. Ekinci. The Cittaslow Policy in the Context of Sustainable Tourism Development: The Case of Turkey, Tourism Management, Vol.41, pp. 178-189, 2014.

[5] H. Mayer, H, P.L. Knox. Small-Town Sustainability: Prospects in the Second Modernity', European Planning Studies, Vol. 18 No. 10, pp.1545-1565, 2010.

[6] W.N. Adger. Social capital, collective action, and adaptation to climate change, Economic Geography. Vol. 79 No.4, pp.387-404, 2003.

[7] C.S. Holling. Resilience and stability of ecological systems, Annual Review of Ecology and Systematics 4. pp. 1-23, 1973

[8] S. Davoudi, S. Resilience: a bridging concept or a dead end?, Planning Theory \& Practice Vol.13, pp. 299-307, 2012.

[9] D. Massey. For Space, Sage, London, 2005.

[10] S. Pink, S., L.J. Servon. Sensory global towns: an experiential approach to the Growth of the Slow City Movement, Environment and Planning A. Vol. 45, pp. 451-466, 2013.

[11] S. Pink, S. Re-Thinking Contemporary Activism: From Community to Emplaced Sociality, Ethnos, Vol. 73 No.2, pp.163-188, 2008. 
[12] D. Massey.World City, Sage, London, 2007.

[13] J. Carp. The Study of Slow in B.E.Goldstein (ed.), Collaborative Resilience: Moving from Crisis to Opportunity, , pp. 99-125, MIT Press, Boston, 2012..

[14] A. Lorentzen, and B. Van Heur, Cultural Political Economy of Small Cities, Routledge, London, 2012..

[15] P.L.Knox and H. Europe's internal periphery: Small towns in the context of reflexive polycentricity in A. Lorentzen and B. van Heur (eds.) Cultural Political Economy of Small Cities, , pp. 142-57, Routledge, London, 2012..

[16] I. Karatas, I. Yenipazarlilar Sakin Sehri Sevmedi, Yeni Asir Newspaper April 2, 2014, Online available from http://www.yeniasir.com.tr/yerelpolitika/2014/04/03/yenipaz arlilar-sakin-sehri-sevmedi

[17] I. Metin. Sakin Sehir Uretmemek Anlamına Gelmiyor, Yap1 Dergi April 2, 2014, Online available from http://www.yapi.com.tr/Haberler/yavas-sehir-uretmemek-anl amina-gelmiyor_124361.html
[18] C. Gunduz. Pragmatism and Utopia Under the Auspices of Neoliberalism: Turning out to be Cittaslow of Seferihisar, $\mathrm{PhD}$ Thesis submitted to the Middle East Technical University, the Graduate School of Social Sciences, 2012.

[19] M.G. Bilgi. Permacultural Conservation, Planning, Management and Educational Practices in the Cittaslow of Turkey, Selcuk Universitesi Sosyal Bilimler Enstitusu Dergisi, Vol. 29, pp.45-59, 2013.

[20] A. Yalcin, S. Yalcin, S. Surdurulebilir Yerel Kalkinma icin Cittaslow Hareketi bir Model Olabilir mi?, Sosyal ve Beseri Bilimler Dergisi. Vol. 5, No.1, pp.32-41, 2013.

[21] O. Ozgen. Seferihisar: A Sustainable Place in a Fast World', Milli Folklor, Vol. 95, pp. '35-46', 2012.

[22] B. Jessop. From Governance to Governance Failure and from Multi-level Governance to Multi-scalar Meta-governance in B. Arts et al. (eds.), The Disoriented State: Shifts in Governmentality, Territoriality and Governance, pp. 79-98, Springer Science + Business Media B. V, 2009. 